\title{
TIG 溶接用タングステン電極の性質*
}

一電流容量㧍よび消耗一

内 ‘田彰**

\section{The Properties of Tungsten Electrode in TIG Arc Welding*}

-Current Cayacity and Consumption-

By Akira Uchida**

\begin{abstract}
In this paper, the author intends to determine the current capacity and consumption of tungsten electrode in TIG arc welding for the purpose of establishing the standard (JIS) of the electrode.

From this work, the following conclusions are obtained :

(1) The current capacity of pure tungsten electrode under DCSP depends on Joule's heat and consequently on the stick-out length of electrode, and is formulated by experiment as $I_{m}=220 \times(a / l e$ $\left.\times 10^{2}\right)^{3 / 4}$, where $a$ is the cross section of electrode in $\mathrm{cm}^{2}$ and le is the stick-out length of electrode in $\mathrm{cm}$. The current capacity of thoriated tungsten in argon shielded DCSP arc is rather a little less than that of pure tungsten.

(2) The DCRP current capacity has not a definite critical value, but is determined from a prac. tial standpoint.

(3) The failure of electrode due to over current in the AC TIG arc occurs in two ways; that is, of S.P. type in smaller diameter electrode and of R.P. type in larger diameter electrode. The AC capacity depends largely on the amount of DC component, and their relation is given by $I_{m}=I_{m 0} /(1$ $-\alpha P d)$, where $\mathrm{I}_{m o}$ is the maximum allowable current in the case of balanced $\mathrm{AC}, P d$ is the ratio of $\mathrm{DC}$ component to effective value of $\mathrm{AC}$ component and $a$ is a theoretically given coefficient. The $\mathrm{AC}$ capacity of thoriated tungsten is considerably larger than that of pure tungsten.

(4) From careful measurements using water-cooled $\mathrm{Cu}$ anode or aluminum plate as a work piece and preventing start spattering, the electrode consumption under DCSP steady arc is found to be a few $\mathrm{mg} / 30 \mathrm{~min}$. and seems to be caused through pure evaporation. The electrode consumption for $\mathrm{AC}$ arc under the same condition is 2 to 3 times the value mentioned above.

(5) For the arc when using steel plate as base electrode, the consumption is nearly 10 times that for DCSP arc with water cooled $\mathrm{Cu}$ anode, and especially in the case of the AC arc successive spattering sometimes accompanies.

(6) At the start of DCSP arc, the spattering of electrode is caused when applying nearly maximum allowable current suddenly to pure tungsten which was once used. Start spattering is not caused by (a) thoriäted tungsten (b) pure, virgin tungsten, (c) arc starting with smaller current.

(7) The start spattering is found to occur succeedingly for about $1 / 4$ sec. following the arc ignition, and seems to be caused by the cavity formed at the tip of electrode and the thermal shock.
\end{abstract}

\section{1. 緒言}

最近，怪金属その他の TIG 溶接において，タングス テンインクルージョンによる欠宿が問題にされ，またい っぼう電極の JIS 作成の要請があった。とれらに関逨 して，電極の許容電流，電極の消耗量，スパッター，了 一クの起動安定拉よびいわゆる交流了ークの直流分, 純

* 原稿受什 明和 38 年 6 月 11 日

**k 正員 铁道技術即行所 Member, Railway Technical Research Institute, J.N.R
タングステンとトリア入りタングステンの比輘などが䦓 題となった。

タングステン電極の一部の性質については，従来 Gibson, Winsor, 安藤扔よび長谷川などの研呪がある が，実際の消耗留のようにデータのまちまちであるもの や，スパッターなどのように現象の明らかとは云えない 事柄が少くない，本研究は以上の問題に答えるために， 抯存の知識を十分に整理検討したうえで，とくに電流容 量と消耗について詳しく吟味したものである. 


\section{2、直流における電流容量}

\section{1 直流正極性アークにおける電流容量}

電極径とその適用電流範囲については，通常たとえば Linde 社の manual ${ }^{1)}$ に示されたあのが用いられてい る. しかし一般に電流容量すなわち最大許容電流值の意 義あるいはその決定根拠については十分には理解されて いなかったと思われる。 (a) (b)

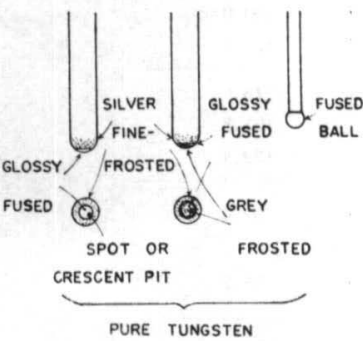

(d)

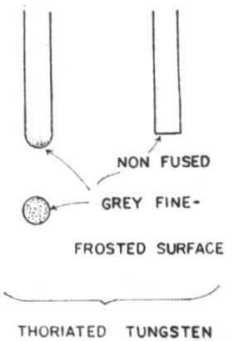

Fig. 1 The appearance of tungsten electrode tip after running at DC straight polarity

Fig. 1 は DCSP の通常使用する電流におけるアーク の発生時または消弧後の電極先端の模様を図解したもの である.いま電流をしだいに上げてゆくと（たとえば 5 10 Amp/3 min. 〈゙らいのはやさで階段的に増す), 終に電極の先端から若干上方の部分において溶融し, そ の下方の部分が脱落するにいたる. これは純 W, Th-W とあ同様である.との電流にいたるまで一般に電極先端 はとくに溶損を起さないし，また溶融部（純W電極の先 端）あるいは灰色部分が電流につれて顕著に拡がること あ認められない（ただし Fig. 1 (c) の溶滴落下の場合 もある). Fig. 2 の写真は溶損を起した例を示すが, 下

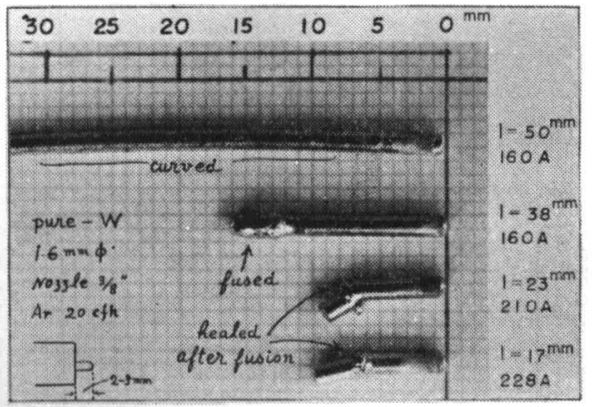

Fig. 2 The fusion damage of W-electrodes by over arc current at DCSP

方の二つは溶融と同時に電流を切ったために溶融部が癔 着したものであり（溶融部は表面張力で縮むためにア一 クは長くなり，したがってアーク電流が一時娍少するか ら,ただちに電流を切れば電極先端部は落下しない).
最上方のむのは電極突出長さをきわめて大きくしたとき に生じた彎曲である（この理由は明らかでないが，溶融 直前に達していると考えられる). Fig. 2 は $1.6 \mathrm{~mm}$ 径 のものを示すが, $2.4 \mathrm{~mm}$ 径の電極では先端と溶融部と の間隔はきわめて短いが,なお先端の近くに明らかに溶 けていない部分の存在が認められる.

以上から，正極性 (DCSP) では許容電流を越した場 合に電極はジュール熱で破買する（このととは Gibson ${ }^{2)}$ む指摘している). したがって電流容量は主としてジュ 一ル熱とその冷却度によってきまり, 最大電流付近では 陰極部またはその近傍はアークによって加熱されるより あむしろ電子蒸発によって冷却されているすのと考えな ければならない。

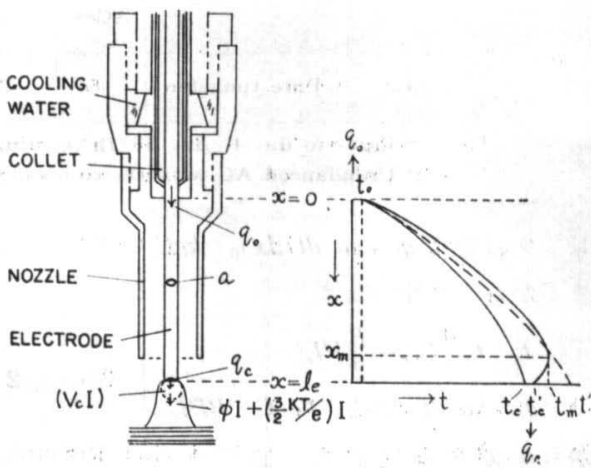

Fig. 3 The illustration of temperature distribution on the electrode of TIG torch

Fig. 3 は電極突出部分（コレットチヤックから先端 まで）の温度分布を図解したもので，許容電流値より十 分低い電流ではたとえば $t_{0} t_{c}$ のような温度になってい るが, 電流が増すと $t_{0} t_{m} t_{c}{ }^{\prime}$ のように極大点を生じ, 最大電流では $t_{m}$ がタングステンの融点に等しいと考え られる.（ただし純 W 電極の陰極点の溶融部は除外して 考えている. この場合, 純 W の院極点はいちじるしい イオンの衝撃を受けるが，その周囲または背後の部分は 比較的イオンの衝撃を受けずに電子蒸発のみ相当存在す るというようなととを考えなければならないであろう. 事実 Fig. 1 (a), (b) に示したような陰極部の複雄な構 造は興味があるが，とこでは触れないととにする).

実際は輻射熱が相当の大さになるが，簡単のために一 次元の熱伝導問題としてこの温度分布を考えれば，つぎ の二次式で表わされることは明らかである。

$$
\begin{aligned}
t-t_{0} & =C x-\frac{B}{2} I^{2} x^{2} \\
B & =\frac{1}{4.18} \cdot \frac{\rho}{k} \cdot \frac{1}{a^{2}}
\end{aligned}
$$

ただしIは電流， $\rho$ は平均比抵抗， $k$ は平均熱伝導度， $a$ は電極断面積である (その他 Fig. 3 参照). 
Table 1 The temperature rise of cooling water of welding torch (HW-10)

\begin{tabular}{|c|c|c|c|c|c|c|c|}
\hline \multicolumn{2}{|c|}{ Electrode } & \multicolumn{2}{|c|}{ Current } & \multicolumn{3}{|c|}{$\begin{array}{c}\text { Readings of } \\
\text { thermometers }\left({ }^{\circ} \mathrm{C}\right) *\end{array}$} & \multirow{2}{*}{$\begin{array}{l}\text { Heat input to } \\
\text { collet (cal/sec) }\end{array}$} \\
\hline dia. (mm) & type & type & $\left(\mathbf{A m p}_{1}\right)$ & (1) & (2) & (3) & \\
\hline \multirow{6}{*}{1.6} & \multirow{3}{*}{ Pure tungsten } & DCSP & 100 & 18.0 & 19.6 & 20.7 & 14.7 \\
\hline & & $"$ & 140 & 18.0 & 20.9 & 23.0 & 28.0 \\
\hline & & $"$ & 170 & 18.0 & 22.5 & 25.6 & 41.3 \\
\hline & \multirow{3}{*}{$\begin{array}{l}\text { Thoriated } \\
\text { tungsten }\end{array}$} & $" \prime$ & 100 & 17.9 & 19.3 & 20.5 & 16.0 \\
\hline & & $"$ & 140 & 17.9 & 20.8 & 23.0 & 29.3 \\
\hline & & $"$ & 170 & 18.0 & 22.8 & 25.9 & 41.3 \\
\hline \multirow{7}{*}{2.4} & \multirow{3}{*}{ Pure tungsten } & $" \prime$ & 200 & 18.1 & 21.2 & 24.6 & 45.3 \\
\hline & & " & 300 & 18.1 & 24.4 & 31.9 & 100.0 \\
\hline & & $"$ & 340 & 18.2 & 27.1 & 36.8 & 129.4 \\
\hline & \multirow{4}{*}{$\begin{array}{l}\text { Thoriated } \\
\text { tungsten }\end{array}$} & $"$ & 200 & 18.3 & 20.9 & 24.5 & 48.0 \\
\hline & & " & 300 & 18.3 & 24.5 & 32.1 & 101.3 \\
\hline & & $"$ & 340 & 18.4 & 27.1 & 36.8 & 129.4 \\
\hline & & $A C^{* * *}$ & 200 & 18.8 & 22.9 & 27.2 & 57.4 \\
\hline 3.2 & Pure tungsten & $" \prime$ & 200 & 18.6 & 22.6 & 27.0 & 58.7 \\
\hline
\end{tabular}

* Refer to fig. 4., Ar. $15 \mathrm{cfh}$; cooling water $0.8 \mathrm{l} / \mathrm{min}$.

** Unbalanced AC with DC component of about $65 \%$

コレットの受熱 $q_{0}=k a(d t / d x)_{0}=k a C$ を夷測すればC が求まるから，原理的には

$$
\left.\begin{array}{l}
t_{c}=t_{0}+C l_{e}-\frac{B}{2} I^{2} l_{e}{ }^{2} \\
q_{c}=k a(d t / d x) l_{e}=k a\left(C-B I^{2} l_{e}\right)
\end{array}\right\}
$$

がかかり，陰極温度の测定值やさらに RichardsonDushman の式あるいはエネルギー平衡の式 $\left(V_{c} I=\phi I+\right.$ $\left.(3 k T / 2 e) I-q_{c}\right)$ との比較ができるはずである. 陰極点 温度については，たとえば Cobine ${ }^{3)}$ はタングステン電 極のをれを $4000^{\circ} \mathrm{K}, 15 \%$ リア入りタングステンでは $3300^{\circ} \mathrm{K}$, Winsor, Turk ${ }^{4}$ は $2500 \sim 3000^{\circ} \mathrm{C}$ を与えてい る、しかし実際にはふく射熱およびガスによる冷却が無 視できないし，陰極部の形状などの問題があるから，

（2）式で十分な議論をすることはやや無理である.

Table 1 は実用トーチ（HW-10）を使用し，ノズル

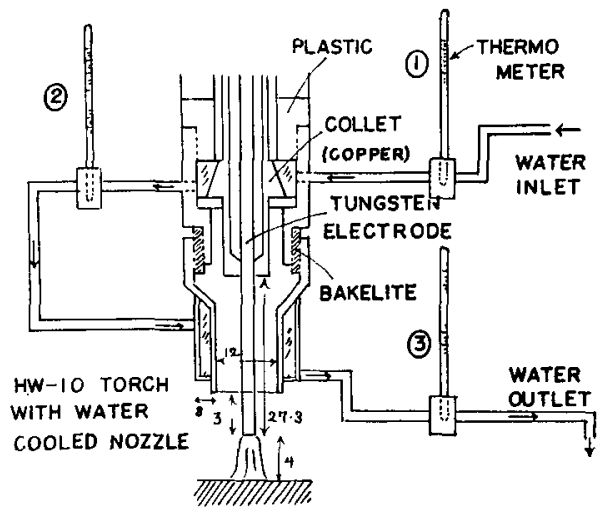

Fig. 4 The measurement of temperature rise of cooling water of TIG torch
部分をやや改変して Fig. 4 に示すような方法で冷却水 の温度上昇を測定したものである．との表の值を用い， たとえば $k=0.3, \rho=50 \times 10^{-6}, l_{e}=2.73 \mathrm{~cm}$ とし（2） 式から $t_{c}$ 在求めれば $1.6 \mathrm{~mm}$ 径 $100 \mathrm{~A}$ のとき $3100^{\circ} \mathrm{C}$, $140 \mathrm{~A}$ のとき $5400^{\circ} \mathrm{C} 2.4 \mathrm{~mm}$ 径 $200 \mathrm{~A}$ のとき $6100^{\circ} \mathrm{C}$ となり最初のむのの他はいちじるしく過大である.これ はふく射熱を全く無視し得ないからで，Fig. $3 の t_{0} t_{c}$ を 実際の温度分布とすれば，(2）式の与えるのは $t_{0} t_{c}{ }^{\prime \prime}$ (点線) のようになるからである。

以上の機構加ら，厳密な計算は困難であるが，電極突 出部の長さを種々に変化させた場合に許容最大電流值が 相当変化するととが考えられ，この知識が実用上は必要

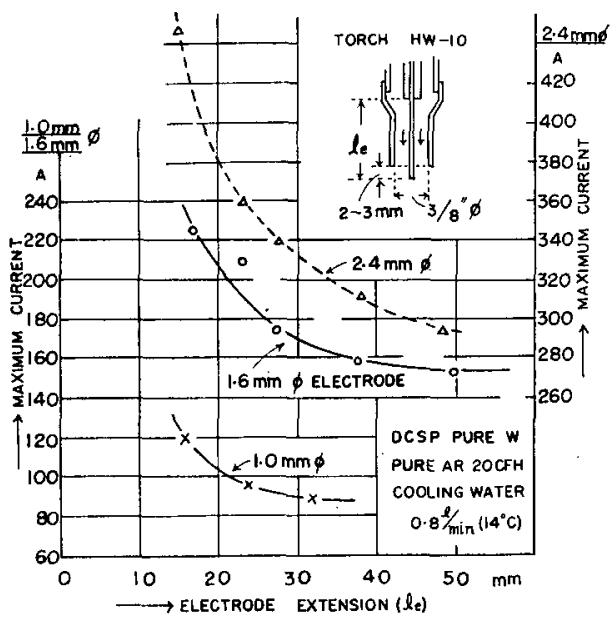

Fig. 5 The current capacity of W-electrode at DCSP related to the electrode extension 
である. Fig. 5 は市販のトーチ (Linde HW-10) を使 用し，異る長さの/ズルを用いて電極突出長さ $\left(l_{\boldsymbol{e}}\right)$ を 変えて実測した例である. 普通のト一千は $l_{e} \approx 3 \mathrm{~cm}$ 程 度になっているが，その付近で $l_{e}$ の変化によって最大 電流值がかなり変化することが知られる。

今単純な考え方により許容電流值は $l_{e}$ に反比例し, 断 面積 $a$ に比例するとみて，実験式として $I_{m}=k\left(a / l_{c}\right.$ × $\left.10^{2}\right)^{n}$ 乙仮定し Fig. 5 の結果を対数グラフに表わせば Fig. 6 のようになり, $n=0.75, \log k=2.35$, すなわち $I_{m}$ は概ね次式で与えられる.

$$
I_{m}=220 \times\left(\frac{a}{l_{e}} \times 10^{2}\right)^{3 / 4}
$$

許容電流值を与えているものは前記 (Table 2), Chapin $ら^{3}$ ) (Table 3), Huff ${ }^{5}$ ) (Table 4) なよ゙である。これらの值は若千の食い違いがあるが，筆

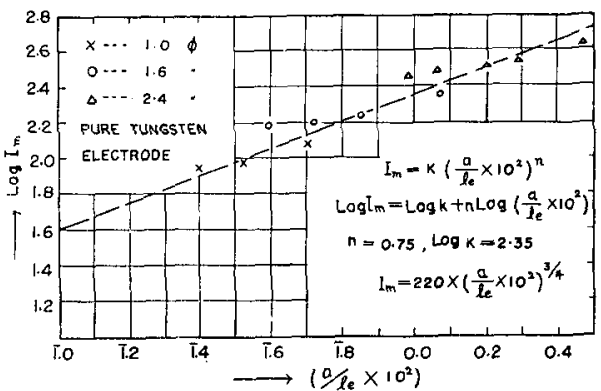

Fig. 6 Logarithmic representation and the experimental formula of current capacity at DCSP
者の試験ような電極突出し長さなどの条件が必ずしむ明 記されていないから，それらの影響にもよるものと考え られる. しかし注目に值するのは純タンとトリタンの相 異および $A_{r}$ と $H_{e}$ の相㟟である. 後者はことでは吟味 することができないか，前者についての筆者の測定は Table 5 のようである. トリタンの場合のほうが純タン 上りも電極先端の温度が低いから, 前記の簡単な理論か

Table 2 Maximum current at DCSP tungsten electrode (after Gibson ${ }^{2}$ )

\begin{tabular}{|c|c|c|c|}
\hline \multicolumn{2}{|c|}{ Electrode } & \multicolumn{2}{|c|}{ Shield gas } \\
\hline Diameter (in) & Ty pe & $\mathrm{He}$ & Ar \\
\hline 0.04 & $\begin{array}{l}\text { Pure-W } \\
\text { Th-W }\end{array}$ & $\begin{array}{l}100 \\
100\end{array}$ & $\begin{array}{r}100 \\
90\end{array}$ \\
\hline $1 / 16$ & $\begin{array}{l}\text { Pure-W } \\
\text { Th-W }\end{array}$ & $\begin{array}{l}190 \\
190\end{array}$ & $\begin{array}{l}190 \\
190\end{array}$ \\
\hline $3 / 32$ & $\begin{array}{l}\text { Pure-W } \\
\text { Th-W }\end{array}$ & $\begin{array}{l}250 \\
375\end{array}$ & $\begin{array}{l}350 \\
340\end{array}$ \\
\hline $1 / 8$ & $\begin{array}{l}\text { Pure-W } \\
\text { Th-W }\end{array}$ & $\begin{array}{r}300 \\
>500\end{array}$ & $\begin{array}{l}>500 \\
>500\end{array}$ \\
\hline
\end{tabular}

Table 3 Electrodrode characteristics (after Chapin $\left.{ }^{3}\right)$ (DCSP)

\begin{tabular}{|c|c|c|c|c|c|}
\hline \multirow[b]{2}{*}{ Electrode* } & \multicolumn{3}{|c|}{$\begin{array}{l}\text { Min. dependable OCV } \\
\text { for starting }\end{array}$} & \multirow{2}{*}{$\begin{array}{c}\text { Operating } \\
\text { current } \\
\text { range (A) }\end{array}$} & \multirow{2}{*}{$\begin{array}{c}\text { Failure } \\
\text { current (A) }\end{array}$} \\
\hline & Copper & $\begin{array}{c}\text { Stainless } \\
\text { steel }\end{array}$ & $\begin{array}{c}\begin{array}{c}\text { Silicon } \\
\text { steel }\end{array} \\
\end{array}$ & & \\
\hline Tungsten & $>95$ & $>95$ & $>95$ & 70 & 400 \\
\hline $1 \% \mathrm{Th}-\mathrm{W}$ & $40-65$ & $55-70$ & $70-75$ & $10-350$ & 385 \\
\hline $15 \% \mathrm{Th}-\mathrm{W}$ & 35 & 40 & 40 & $6-310$ & 350 \\
\hline
\end{tabular}

* $3 / 32^{*} \phi$, pointed

** 1/16* arc length, 15 cfh Ar, HF starting

Table 4 Current capacity of electrode (after Huff ${ }^{5}$ )

\begin{tabular}{|c|c|c|c|c|c|c|c|c|c|c|c|}
\hline \multirow{3}{*}{$\begin{array}{c}\text { Electrode } \\
\text { diam. } \\
\text { (in) }\end{array}$} & \multirow{3}{*}{$\begin{array}{c}\text { Gas } \\
\text { nozzle } \\
\text { size } \\
\text { (in) }\end{array}$} & \multirow{3}{*}{$\begin{array}{l}\text { Gas } \\
\text { flow } \\
\text { (cfh) }\end{array}$} & \multicolumn{5}{|c|}{$\overline{\mathrm{D}} \overline{\mathrm{C}(\mathrm{A})}$} & \multicolumn{4}{|c|}{$\overline{\mathrm{AC}}(\overline{\mathrm{A}})$} \\
\hline & & & \multirow{2}{*}{\multicolumn{2}{|c|}{$\frac{\text { R.P. }}{\text { Standard W }}$}} & \multicolumn{3}{|c|}{ S.P. } & \multicolumn{4}{|c|}{ Standard tungsten } \\
\hline & & & & & \multicolumn{2}{|c|}{ Standard $W$} & $\frac{1 \% \mathrm{Th}-\mathrm{W}}{\text { Heor Ar }}$ & \multicolumn{2}{|c|}{ Balanced AC } & \multicolumn{2}{|c|}{$\begin{array}{l}\text { Standard trans- } \\
\text { former with HF }\end{array}$} \\
\hline .04 & $1 / 4-3 / 8$ & $8 \sim 12$ & $<10$ & \multirow{5}{*}{ Not used } & $<50$ & $<65$ & $12 \sim 100$ & $<25$ & $<35$ & \multirow{5}{*}{ Not used } & $<30$ \\
\hline $1 / 16$ & $1 / 4 \sim 3 / 8$ & $10 \sim 16$ & $10-20$ & & $40 \sim 125$ & $65 \sim 150$ & $20 \sim 190$ & $20 \sim 60$ & $30-85$ & & $20 \sim 115$ \\
\hline $1 / 8$ & $3 / 8-1 / 2$ & $15 \sim 30$ & $25-50$ & & $200 \sim 300$ & $250 \sim 375$ & $50 \sim 475$ & $75 \sim 175$ & $100-200$ & & $150 \sim 225$ \\
\hline $3 / 16$ & $1 / 2$ & $15 \sim 30$ & $30-75$ & & $250 \sim 350$ & $300 \sim 475$ & - & $150 \sim 240$ & $175 \sim 300$ & & $200 \sim 340$ \\
\hline $1 / 4$ & $1 / 2$ & $15 \sim 30$ & $40-125$ & & $300 \sim 475$ & $420 \sim 475$ & - & $200 \sim 330$ & $275-400$ & & $300 \sim 400$ \\
\hline
\end{tabular}

Table 5 DCSP current capacity of pure and thoriated tungsten in comparison

\begin{tabular}{|c|c|c|c|c|}
\hline \multicolumn{2}{|c|}{ Electrode } & \multirow{2}{*}{$\begin{array}{l}\text { Current cap. (A) } \\
\text { (Failure current) }\end{array}$} & \multirow{2}{*}{$\begin{array}{l}\text { Length of electrode } \\
\text { after failure from } \\
\text { collet end ( } \mathrm{mm})\end{array}$} & \multirow{2}{*}{$\begin{array}{l}\text { Temperature rise of } \\
\text { coolling water of } \\
\text { collet }\left({ }^{\circ} \mathrm{C}\right)\end{array}$} \\
\hline Dia. $(\mathrm{mm})$ & Type & & & \\
\hline 1.6 & $\begin{array}{l}\text { Pure tungsten } \\
2 \% \text { thoriated }\end{array}$ & $\begin{array}{ll}190 & (195) \\
175 & (185)\end{array}$ & $\begin{array}{l}14.5 \\
15.3\end{array}$ & $\left.\begin{array}{l}3.1 \\
3.1\end{array}\right\} \begin{array}{l}\text { at } \\
170 \mathrm{~A}\end{array}$ \\
\hline 2.4 & $\begin{array}{l}\text { Pure tungsten } \\
2 \% \text { thoriated }\end{array}$ & $\begin{array}{l}350(360) \\
350 \quad(360)\end{array}$ & $\begin{array}{l}16.8 \\
17.0\end{array}$ & $\left.\begin{array}{l}9.7 \\
9.7\end{array}\right\} \begin{array}{l}\text { at } \\
340 \mathrm{~A}\end{array}$ \\
\hline
\end{tabular}

(Remark) Measured in the same condition as table 1 (Fig. 4) 
ら考えると，電流容量が大きいように思われるが，害際 ははとんよ゙变らずむしろいくぶん逆のようである。トリ タンのほうが純タンより多少瀜点が低いことも考元られ るが，細部の理解はな竹研究を要する. Huff の表の值 はやや疑問似思放礼る。

\section{2 直流逆極性アークにおける電流容量}

逆極性に氺いては電極先端（陽極点）は電子の射入に より加熱されるから，正極性の場合上りはるか比許容電 流が小さくなるととはすでによく知られているるくく射 熱を無視すれば陽極の受ける熱は $Q_{a} \doteqdot\left(\phi+V_{a}\right) \times I / 4.18$, 前節の所諭と同様にして電極先端において電極方向人の 伝導熱 $q_{x=l e}$ は,

$$
q_{x=l_{e}}=k a\left(t_{a}-t_{0}\right) / l_{e}-\frac{1}{8.36} \rho l_{e} I^{2} / a
$$

最大電流のときは $t_{a}=t_{m}$ (融点) で， $q_{x=l_{e}}=Q_{a}$ 之若え られる. 今 $k=0.3, t_{m}=3400, t_{0}=50, p=50 \times 10^{-6}, \phi=$ 4.5, $V_{a}=3$ とすれば,

$$
\begin{aligned}
I_{m} & =\left[\sqrt{\left(\frac{\phi_{a}+V_{a}}{\rho}\right)^{2}+\frac{8.36 k\left(t_{a}-t_{0}\right)}{\rho}}-\frac{\phi_{a}+V_{a}}{\rho}\right] \frac{a}{l_{e}} \\
& =\frac{4.18 k\left(t_{a}-t_{0}\right)}{\left(\phi_{a}+V_{a}\right)} \frac{a}{l_{e}} \fallingdotseq 6 \times 10^{2} \frac{a}{l_{e}} \quad \cdots \cdots \cdots \cdots . . .
\end{aligned}
$$

てれは大体の大さ老説明するが，撖密には実際と一致し ないそれれはふく射熱を無視できないのみならず，ての 場合電極の長さに比して太さが大きくチャック部の温度 ( $\left.t_{0}\right)$ が害際上一定とみなし難く，また先端が大きな球状 になったりすることによるあのである.

今小さいアーク電流からしだいに電流を增した場合の 電極（陽極）の模様を索朴伅観察すると順次以下の上う になる。

（1）純タン、トリタンともごく低い電流では電極は 溶けず，初的形保っている。

（2）電流が増すと先端が円筒形の場合は角が丸くな りあるいは中央があり上る．ある電流に達すると先端 がほぼ半球状になる。

（3）さらに電流が增すと先端は電極径より大きな溶 球となり，したがって先端はそれだけノズルの方へ引っ 込吉．この溶球の表面は流机動いているように見引れる (アークが長くなると電流が下るから溶球はなかなか落 下にいたらない)，電流が階段状僧し，電極先端がや や急に変化すると，(抢そらく $\mathbf{w}$ 蒸気により)電極前面 のアークが青く色つくくとくにトリタンでは整特アーク がいちじるしく青くなる。

（4）な扔，電流加增すと溶球は大きくなり摇れ動 々。乙の溶球の中には一般にがス孔があり，しばしばス パッターらしいものを生ずる.したがって先端はさらに 引っ込む。このスパッターは一部ガスの透出であるう之 思われる。

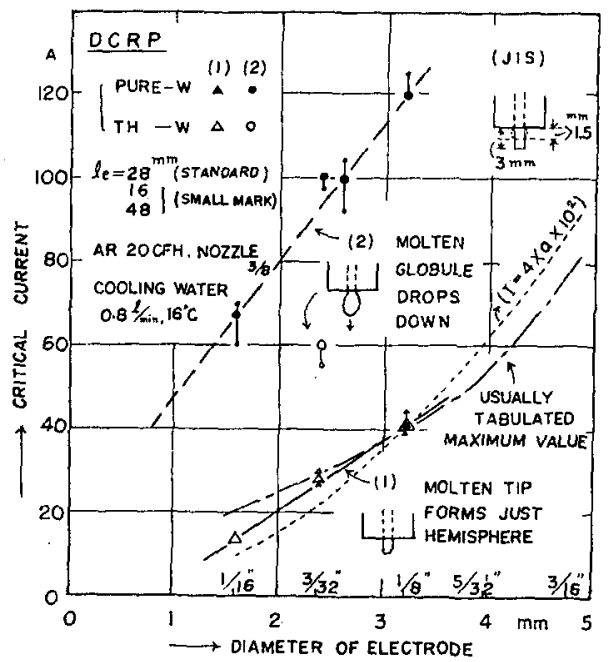

Fig. 7 The current capacity and critical current of W-electrode at DCRP

（5）さらに電流を増すと，先端の溶球は一挙に滴下 し，新しい溶球を生じ，電極先端はノズル内に引っ込九 でしまう。

Fig. 7 は（2）の後の項と（5）項に相当する笔流の 実測值を通常表示されている許容電流値》上と屯に示し たものである. 後者は電極先端がほぼ半球澾する電流 值と近い。なお，JIS 案6ではノズルから先きの電極長 さが初め (3 mm とする) の半分以下にならないという ことで便宜的な判定基準にしている.

な招 Fig. 7 のいずれの電流值も丽極突出長さによる 変化が顕著でないのは，（4）式が実際とよく合わない 理由と同じ理由によるであるう。またトリタンの場合の 滴下の電流值が純タンのそれよりいちじるしく小さいて とは，溶融したトリタンの表面張力が純タンより小さい ことを示すのではないかと想像される。

\section{3．交流における電流容量}

\section{1 交流アークにおける直流分の測定}

交流アークの場合化直流分を生ずるこ上はよく知られ ているが7，Tuthi18) 亿よれば $150 \mathrm{~A}$ の上き直流分は $44 \% ， 400 \mathrm{~A}$ のとき $33 \%$ という例を示している。しかし 筆者らが通常使用しているような溶接機で実験した結果 では直流分はさらにいちじるしいようである．Fig. 8,9 は奥氏（松下電器）に依頼した試験の結㳭であり Table 6 㹥筆者の試験結果である. 電極の種類による 変化を調べるにはデータが不十分のうらみがあるが，卜 リタンのほうが淔流分が大きいであるうという予想は必

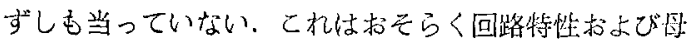

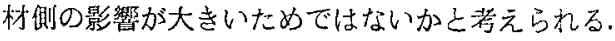




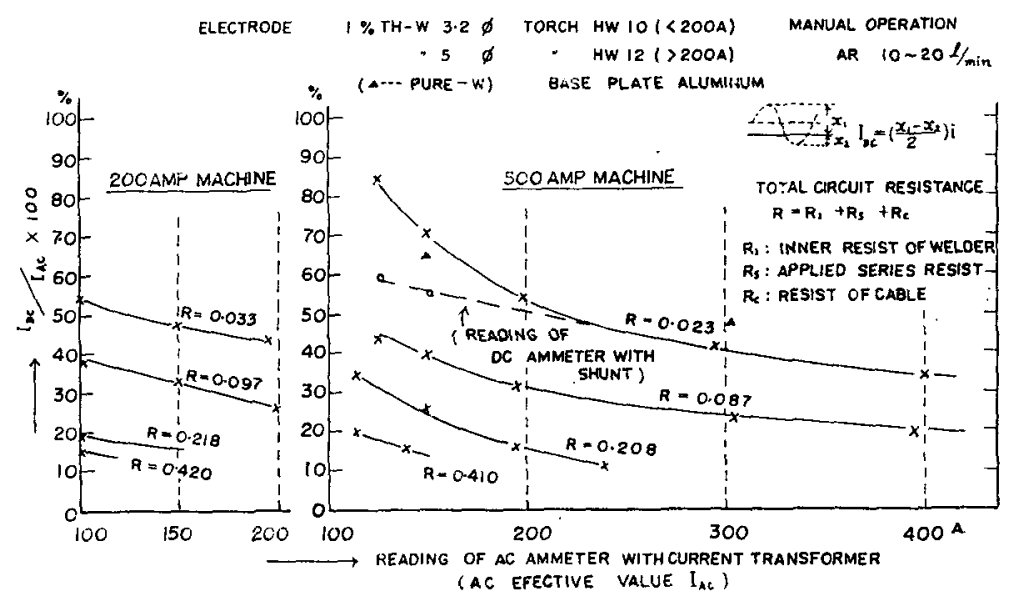

Fig. 8 The direct current component in the arc current of TIG arc welding
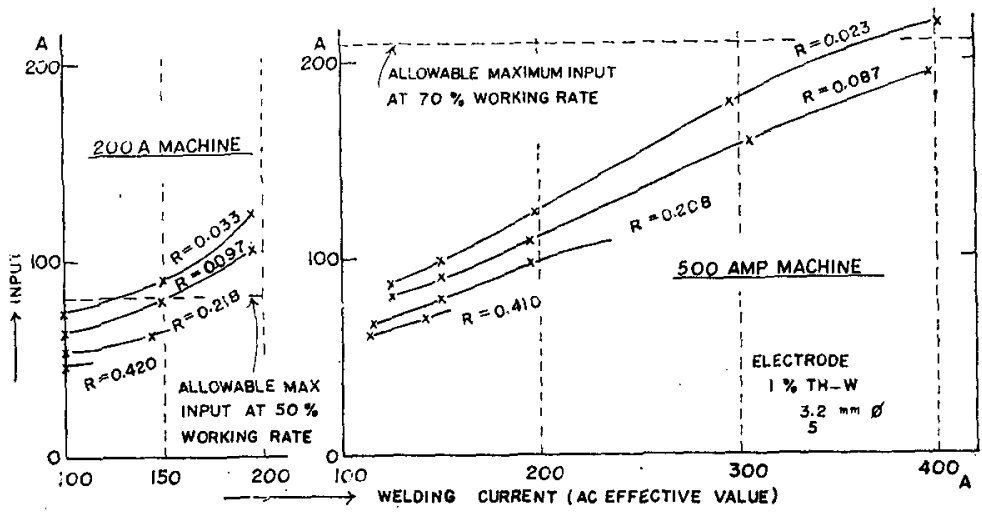

Fig. 9 The change of the primary input of welding machine used to TIG arc welding

Table 6 DC component in arc current of AC TIG arc welding, (400 Amp. machine, $\mathrm{HW}-10, \mathrm{Ar})$

\begin{tabular}{|c|c|c|c|c|c|c|}
\hline \multirow{2}{*}{$\begin{array}{l}\text { Electrode } \\
\text { diameter } \\
(\mathrm{mm})\end{array}$} & \multicolumn{3}{|c|}{ Pure tungsten } & \multicolumn{3}{|c|}{$2 \%$ thoriated tungsten } \\
\hline & $A C$ & DC & DC/AC\% & $\mathrm{AC}$ & $\mathrm{DC}$ & $\mathrm{DC} / \mathrm{AC} \%$ \\
\hline 1 & & & & $\begin{array}{l}73 \\
78\end{array}$ & $\begin{array}{l}49 \\
54\end{array}$ & $\begin{array}{l}67 \\
70\end{array}$ \\
\hline \multirow{2}{*}{1.6} & $\begin{array}{r}82 \\
110 \\
120\end{array}$ & $\begin{array}{l}67 \\
74 \\
75\end{array}$ & $\begin{array}{l}82 \\
67 \\
63\end{array}$ & $\begin{array}{l}72 \\
79 \\
90\end{array}$ & $\begin{array}{l}62 \\
67 \\
69\end{array}$ & $\begin{array}{l}86 \\
85 \\
76\end{array}$ \\
\hline & & & & $\begin{array}{r}78 \\
118 \\
150\end{array}$ & $\begin{array}{l}62 \\
88 \\
93\end{array}$ & $\begin{array}{l}80 \\
75 \\
62\end{array}$ \\
\hline 2.4 & $\begin{array}{l}100 \\
130 \\
160 \\
180\end{array}$ & $\begin{array}{r}79 \\
107 \\
132 \\
131\end{array}$ & $\begin{array}{l}79 \\
82 \\
83 \\
73\end{array}$ & $\begin{array}{l}100 \\
150 \\
200\end{array}$ & $\begin{array}{r}67 \\
96 \\
126\end{array}$ & $\begin{array}{l}67 \\
64 \\
63\end{array}$ \\
\hline 3.2 & $\begin{array}{l}118 \\
165\end{array}$ & $\begin{array}{r}90 \\
126\end{array}$ & $\begin{array}{l}76 \\
76\end{array}$ & & & \\
\hline
\end{tabular}

Table $\eta$ The maximum allowable current and failure current (shown in the brackets) of AC TIG arc welding

\begin{tabular}{c|c|c|c|c}
\hline $\begin{array}{c}\text { Electroce } \\
\text { diameter } \\
(\mathrm{mm})\end{array}$ & \multicolumn{2}{|c|}{ Unbalanced AC* } & \multicolumn{2}{|c}{ Balanced AC** } \\
\cline { 2 - 4 } & Pure W & $2 \%$ Th-W & Pure W & $2 \%$ Th-W \\
\hline 1 & - & $75(80 \dagger)$ & - & - \\
1.6 & $110(160+)$ & $140(160 \dagger)$ & - & - \\
2.4 & $170(220+\dagger)$ & 250 & $100(>210+\dagger)$ & 125 \\
3.2 & 220 & - & $150(250+\dagger)$ & - \\
\hline
\end{tabular}

* With $\mathrm{DC}$ component shown in table 6 ,

** with series condenser

+ Fusion break (S.P. type failure)

$\dagger \dagger$ Fusion drop (R.P. type failure)

\section{2 交流アークにおける電極形態と最大許容電流}

交流アークにおりる電流容量と直流アークにおけるる れ之の関倸が完全に理解しうれい゙本節の問題はかたずく わげである.そのためには（1）極性上極での熱発生の 関係（2）許容最大電流を判走する二通りの根拠，(3) 直流分の大さの 3 点について考慮することが必要であ 
りそのおのおのについてはすでに記したとおりであ る.

Table 7 は筆者が試験した結果であるが, 最大許容電 流の判定は, 電極先端に生じる溶球が大きくなって極度 に振動したり，またはノズルの中にひっ込んでしまって 実用し得ない状態に達することをあってした. すなわち DCRP のときとほぼ同様である. この值は従来のあの1) とあまり変っていない. また同表中カッコ内は電極の破 壊または溶損する電流值であって, 不平衡電流の場合, $1.6 \mathrm{~mm}$ 径以下の電極では DCSP の場合と同様な破壊を 起し, その電流值は DCSP のときの值に近い. また $2.4 \mathrm{~mm}$ 径以上では DCRP と同様に電極先端が溶融滴 下する.

許容電流以内においては純タン電極の先端は正しい球 状を呈しているが, トリタンの場合はこぶ状の溶融凸起 が生じ, かつ不規則に生滅変化している. このため交流 アーク溶接にはトリタン電極の使用を避けるととあある (Fig. 10).

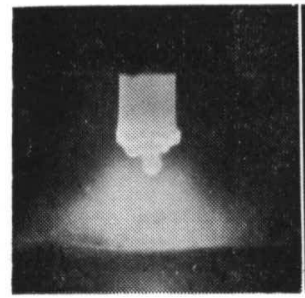

(a) 1st run

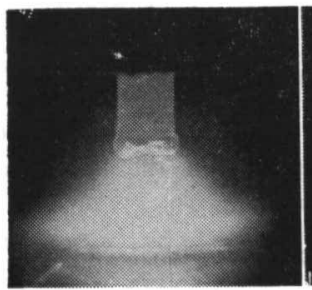

(b) 3rd run

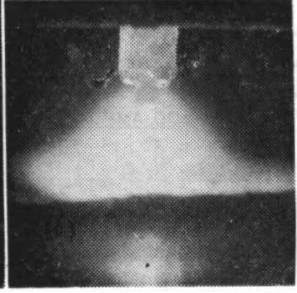

(c) 5 th run

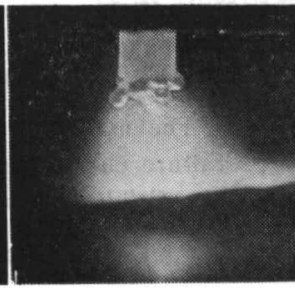

(d) 6 th run
Fig. 10 The formation of irregular projections in the running of $\mathrm{AC}$ arc using $2 \% \mathrm{Th}-\mathrm{W}$ electrode

(225 280 A (unbalanced AC), $2.4 \mathrm{~mm} \phi$, $52 \mathrm{~S}$ plate, each run $34 \mathrm{~cm} / 1 \mathrm{~min}$.)

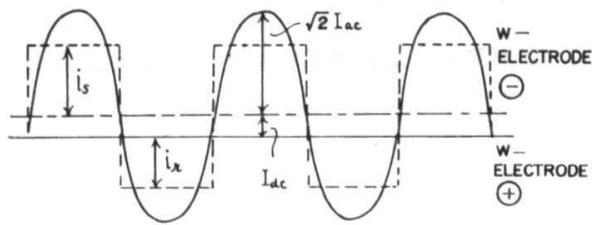

Fig. 11 The illustration of unbalanced AC of TIG arc
安藤, 長谷川 ${ }^{7}$ にると, 純平衡交流の場合, 陰極と しての発熱を陽極のそれに対して無視し，かつ陽極のア ムペア当りの発熱を一定と仮定すると，乙の場合の電流 容量は陽極としての $(D C R P)$ 電流容量の $2 \times 1.1$ 倍とな るはずであり，概ねそうなっている（1.1 は交流の波形 率). 直流分を含むときはつぎのように考えるととがで きる. すなわち Fig.11 について，タングステン電極の 陰極降下 $V_{c}$, 陽極降下 $V_{a}$ が変らないむのとし, 正逆 の各半サイクルの時間を等しいとすれば（厳密にはそう でないが), タングステン電極の入熱は正極性半サイク ルにおいて,

$$
q_{S}=\left(V_{c}-\phi\right) i_{S} \times \frac{1}{100}
$$

逆極性半サイクルで,

$$
q_{r}=\left(V_{a}+\phi\right) i_{r} \times \frac{1}{100}
$$

ただし $i_{S}, i_{r}$ はそれぞれ正および逆極性サイクルの平均 電流である.したがって毎秒の入熱は,

$$
Q=50\left(q_{S}+q_{r}\right)=\frac{1}{2}\left[\left(V_{c}-\phi\right) i_{S}+\left(V_{a}+\phi\right) i_{r}\right]
$$

アーク電流の交流実効值を $I_{a c}$, 直流分を $I_{d}, I_{d} / I_{a c}=P_{d}$ とすれば,

したがって、

$$
\left\{\begin{array}{l}
1 / 2\left(i_{S}-i_{r}\right)=\frac{I_{d}}{2}=\frac{P_{d}}{2} I_{a c} \\
1 / 2\left(i_{S}+i_{r}\right)=\frac{2 \sqrt{2}}{\pi} I_{a c}=0.9 I_{a c}
\end{array}\right.
$$

$$
\left\{\begin{array}{l}
i_{S}=\left(0.9+\frac{P_{d}}{2}\right) I_{a c} \\
i_{r}=\left(0.9-\frac{P_{d}}{2}\right) I_{a c}
\end{array}\right.
$$

ゆえに

$$
Q=\left[0.45\left(V_{c}+V_{a}\right)-\frac{P_{d}}{4}\left(2 \phi+V_{a}-V_{c}\right)\right] I_{a c}
$$

今, 最大交流電流を $I_{a c m}$ とし $P_{d}=0$ (平衡交流) のと きのそれを $I_{a, c, m}^{0}$ と記し, 抵抗熱の変化などを考慮に 入れないとととすれば両者の $Q$ が等しい（一定）と考 えて,

$$
\begin{aligned}
& {\left[0.45\left(V_{c}+V_{a}\right)-\frac{P_{d}}{4}\left(2 \phi+V_{a}-V_{c}\right)\right] I_{a c, m}} \\
& \quad=0.45\left(V_{c}+V_{a}\right) I_{a c, m}{ }^{0}
\end{aligned}
$$

したがって，

$$
\left.\begin{array}{rl}
I_{a c, m} & =\frac{I_{a c, m}^{0}}{1-\alpha P_{d}} \\
\text { たた゚し } a & =\frac{\left(2 \phi+V_{a}-V_{c}\right)}{1 \cdot 8\left(V_{c}+V_{a}\right)}
\end{array}\right\},
$$

ゆえに純タン電極に対し， $\phi=4.5, V_{c} \approx 4, V_{a} \approx 3$ とすれ ば $a \approx 0.6$, したがって $P_{d} \approx 0.7$ のとき

$$
\begin{array}{ll}
I_{a c, m^{0}}=100(\mathrm{~A}) & \text { なら } I_{a c, m} \approx 170 \\
I_{a c, m^{0}}=150 & \text { なら } I_{a c, m} \approx 250
\end{array}
$$

となる. 以上の取り扱いはやや粗雑であるから実測値と 
の完全な一致は得られないが，大体の程度と傾向は説明 し得ている.

トリタンの場合は直流時と交流時の，すなわち温度に よって電極先端の形態の差がいちじるしく，平衡交流て はほとんじ純タンと近い状態で動作していると思われる が, 直流分の多いときは先端温度がいちじるしく下がり うるということを考えなければならない，また細い電極 では抵抗熱の影響も大きくなるであろう。しかし本質的 には以上と同様としても差支えないであるう。トリタン に対しては通常 $\phi$ は $2.7 \mathrm{~V}$ 程度にあたえられているが $V_{c}$ 屯当然低くなるはずである．今 $V_{c} \approx 2$ 程度と仮定す れば， $a \approx 0.7$ 上なり Table 7 の值が説明しうる。

以上いづれも $V_{c}$ の值をかなり低く推定している点に やや問題があるが，逆極性半サイクルに扔いて電極先端 が過熱されていることと $V_{c}$ は平均值として考えている ことなどを考慮すれば必ずしも無理ではないであろう。 また Table 4 その他の従来与えられている平衡交流の 電流容量は大きすきているように思利狆る。

\section{4. 電 極の消 耗}

\section{1 定常的な消耗}

電極の材質の良否や，電流容量決定の根拠として電槡 の正常または異常消耗について吟味する必要があるが，
現在までのととろ十分確かな知識は存在していないとい える。

消耗は，（1）蒸発等の定常的な消耗，（2）アーク発 生時の異常消耗，（3）点弧中の:スパッタ（あるいは spitting）などの異常消耗に分けて考えられる.

従来発表されたタングステン電極の消耗聂の実測值を Table 8 にまとめてある。乙れによると测定值には相 当大きな開きがあり，純チタン，トリタンなよ゙の電極の 種類による差もいづれが大か決定し難い，また直流ア一

Table 9 The consumption of tungsten electrode during $30 \mathrm{~min}$, arc running (DCSP, Arshield, water-cooled $\mathrm{Cu}$ anode)

\begin{tabular}{c|c|c|c}
\hline $\begin{array}{c}\text { Electrode } \\
\text { diameter } \\
(\mathrm{mm})\end{array}$ & $\begin{array}{c}\text { Type of } \\
\text { electrode }\end{array}$ & $\begin{array}{c}\text { Arc current } \\
\text { (Amp. DCSP) }\end{array}$ & $\begin{array}{c}\text { Consumtion* } \\
\text { of electrode } \\
\text { (mg) }\end{array}$ \\
\hline 1 & $\begin{array}{l}\text { Pure-W } \\
2 \% \text { Th-W }\end{array}$ & 80 & $\begin{array}{l}1.9 \\
0.9\end{array}$ \\
\hline 1.6 & $\begin{array}{l}\text { Pure-W } \\
2 \% \mathrm{Th}-\mathrm{W}\end{array}$ & 150 & $\begin{array}{l}1.5(2.3) \\
1.6(2.86)\end{array}$ \\
\hline 2.4 & $\begin{array}{l}\text { Pure-W } \\
2 \% \mathrm{Th}-\mathrm{W}\end{array}$ & 250 & $\begin{array}{l}1.5(1.99) \\
1.2(2.14)\end{array}$ \\
\hline 3.2 & $\begin{array}{l}\text { Pure-W } \\
2 \% \mathrm{Th}-\mathrm{W}\end{array}$ & 400 & $\begin{array}{l}3.2(7.28) \\
3.3(5.65)\end{array}$ \\
\hline 4.0 & $2 \% \mathrm{Th}-\mathrm{W}$ & $(5 \mathrm{~min})$ & 1.7 \\
\hline
\end{tabular}

* Typical value from $2 \sim 4$ test specimens, Figures in brackets are maximum values

Table 8 The consumption of tungsten electrode in steady state arc (after eddited literatures)

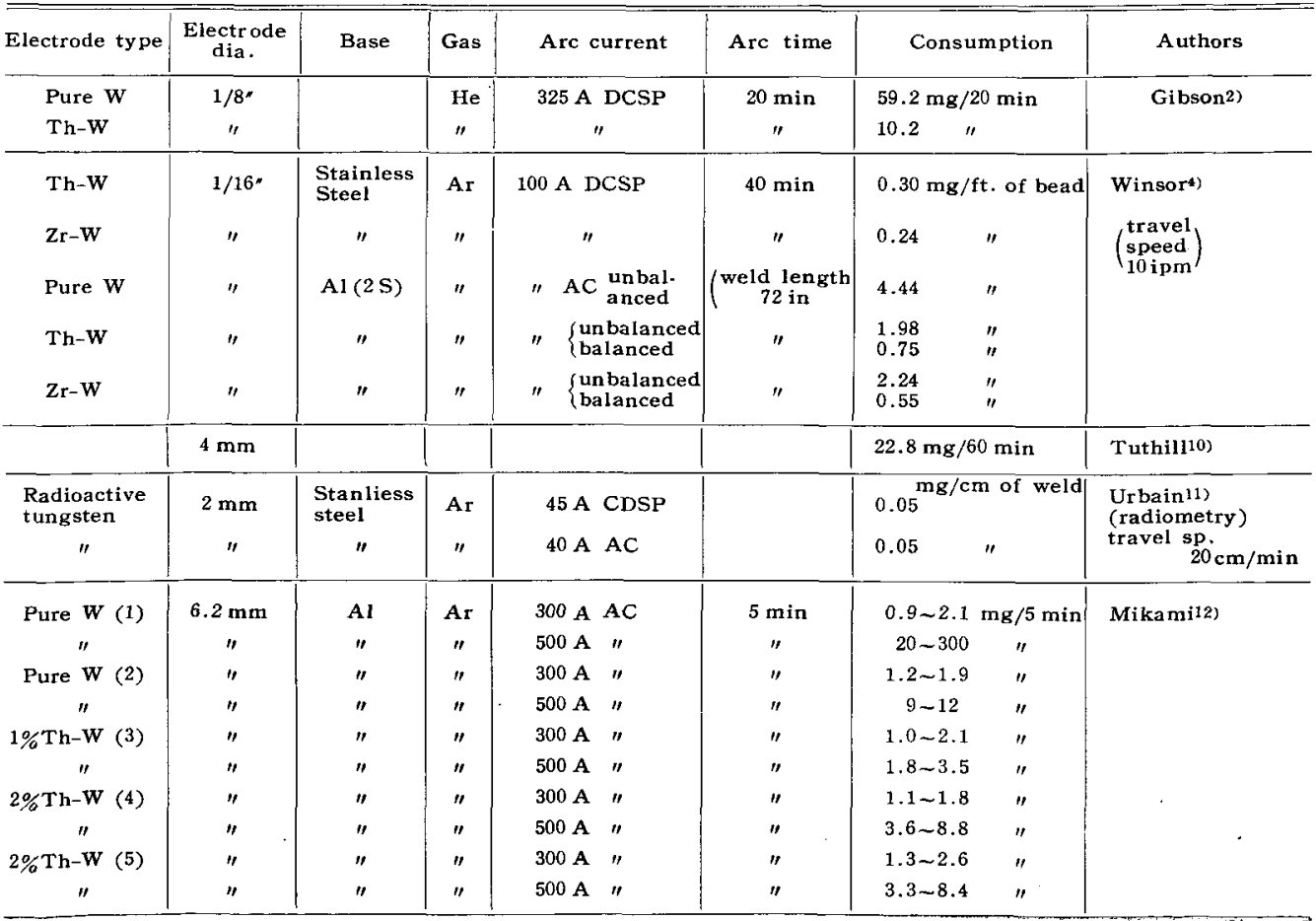


Table 10 The consumption of W electrode $\mathrm{tn} \mathrm{AC}$ arc, (Workpiece Al $52 \mathrm{~S}$ plate, manual operation, Ar $15 \mathrm{cfh}$, arc length $5 \mathrm{~mm}$ )

\begin{tabular}{|c|c|c|c|c|c|}
\hline Electrode & $\begin{array}{l}\text { Current* } \\
\text { (Amp.) }\end{array}$ & $\begin{array}{c}\text { Arc time } \\
\text { (min.) }\end{array}$ & Machine & $\begin{array}{c}\text { Consumption } \\
\text { (mg) }\end{array}$ & Remarks \\
\hline $\begin{array}{l}\text { Pure W } \\
2.4 \mathrm{~mm} \phi\end{array}$ & $\begin{array}{c}90 \sim 100 \\
\prime \prime \\
120 \sim 135 \\
\prime \prime \\
155 \sim 160\end{array}$ & $\begin{array}{l}5 \\
" 1 \\
" 1 \\
"\end{array}$ & $\begin{array}{l}\mathbf{N} \\
\mathbf{H} \\
\mathbf{N} \\
\mathbf{H} \\
\mathbf{N}\end{array}$ & $\begin{array}{l}1.16 \\
1.00 \\
1.89 \\
1.47 \\
2.86\end{array}$ & $\begin{array}{c}\text { Average of } 2 \text { samples } \\
\qquad " \\
\text { Average of } 4 \\
\text { Average of } 2\end{array}$ \\
\hline $\begin{array}{l}\text { Th-W } \\
2.4 \mathrm{~mm} \phi\end{array}$ & $\begin{array}{c}120 \sim 130 \\
\prime \prime \\
140 \\
210 \sim 220 \\
235 \\
250\end{array}$ & $\begin{array}{r}10 \\
20 \\
5 \\
" 1 \\
11 \\
3\end{array}$ & $\begin{array}{l}\mathbf{H} \\
" \\
\mathrm{~N} \\
" \\
" \\
"\end{array}$ & $\begin{array}{l}1.83 \\
2.75 \\
0.79 \\
1.98 \\
3.03 \\
233\end{array}$ & $\begin{array}{l}\text { Average of } 2 \\
\qquad " \\
\qquad \begin{array}{c}\text { One sample, other } \\
\text { shows } 15.92 \mathrm{mg} * *\end{array} \\
\text { Melt dropped }\end{array}$ \\
\hline
\end{tabular}

* Effective value of $\mathrm{AC}$ component of unbalanced $\mathrm{AC}$

**. The cause of anormaly is unknown

Table 11 The consumption of $\mathrm{W}$ electrode in $\mathrm{AC}$ arc (Fixed torch, workpiece $\mathrm{Al}$ (2S) turning $\backslash$ disk, Ar $15 \mathrm{cfh}, 3 \sim 4 \mathrm{~mm}$ arc)

\begin{tabular}{|c|c|c|c|c|c|c|}
\hline Type of $w$ & Elect. Dia. & Current & DC Comp. & Arc time & Consumption & Remarks \\
\hline Pure W & $1.6 \mathrm{~mm}$ & $110 \mathrm{~A}$ & with & $30 \mathrm{~min}$ & $9.06 \mathrm{ng}$ & \multirow{4}{*}{$\begin{array}{l}\text { Arc was once intermitted } \\
\left\{\begin{array}{l}\text { Ar-cylinder pressure } \\
\text { was lowest }\end{array}\right. \\
\left\{\begin{array}{c}\text { Electrode was somewhat } \\
\text { oxidized after stopped }\end{array}\right.\end{array}$} \\
\hline$" \prime$ & $"$ & $"$ & $"$ & $" \prime$ & 7.32 & \\
\hline Th-W & $"$ & $"$ & $"$ & $"$ & 6.52 & \\
\hline$" \prime$ & $"$ & " & " & 29 & 12.55 & \\
\hline Pure-W & 2.4 & 150 & $"$ & 28 & 6.56 & \multirow{4}{*}{$\begin{array}{l}\text { Arc was once intermitted, } \\
\text { with some like sputtering }\end{array}$} \\
\hline$"$ & $"$ & $"$ & $" \prime$ & 30 & 21.72 & \\
\hline Th-W & $"$ & $"$ & $"$ & " & 4.17 & \\
\hline$"$ & $"$ & $" \prime$ & $"$ & $"$ & 4.35 & \\
\hline$"$ & $"$ & 200 & $" \prime$ & 15 & 12.06 & Tip was oxidized after stopped \\
\hline Pure-W & 3.2 & 150 & $" \prime$ & 30 & 3.68 & \multirow{4}{*}{$\begin{array}{l}\text { With some like sputtering } \\
\left\{\begin{array}{l}\text { Molten metal dropped twice in } \\
\text { the way }\end{array}\right.\end{array}$} \\
\hline$"$ & " & 200 & " & 25 & 15.20 & \\
\hline$"$ & " & $\begin{array}{c}200 \\
(190 \sim 240)\end{array}$ & $"$ & 17 & 183.79 & \\
\hline$T h-W$ & $"$ & 150 & " & 30 & 2.58 & \\
\hline Pure W & 2.4 & $85 \sim 90$ & without* & 30 & 4.42 & \multirow{4}{*}{$\begin{array}{l}\left\{\begin{array}{c}\text { Electrode was somewhat } \\
\text { oxidized after stopped }\end{array}\right. \\
\text { Arc was somewhat unstable }\end{array}$} \\
\hline Th-W & $"$ & " & " & 30 & 11.86 & \\
\hline Pure W & $\varepsilon \cdot 2$ & 150 & $"$ & 30 & 13.27 & \\
\hline Th-W & $" \prime$ & " & $"$ & 30 & 14.19 & \\
\hline
\end{tabular}

* Appling serties condenser

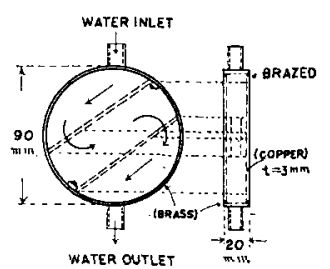

(a)

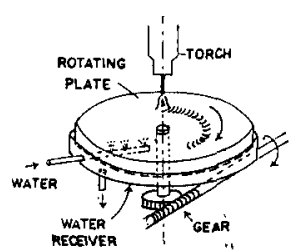

(b)
Fig. 12 The base electrode for measurement of consumption of $\mathrm{W}$-electrode
クと交流アークでは後者の方が消耗量が大きいようであ るが，判然とはしていない。

Table 9 12 は簐者の测定結果である.母板としては 水冷銅電極（Fig. 12(a), Table 9) または水冷回転円板 (Fig. 12(b), Table 11,12) を用い. トーチは固定し, アークをスクリーンに撮影観察した。また一部は普通の 試験板を用い，トーチを手動操作した。な技等者の测定 では，後記のようにアーク起動時のスパッタを避けるた めに，起動時の電流は最大竍容電流の半分程度とし，ス 
Table 12 The consumption of $\mathrm{W}$ electrode in the case of steel work piece (turning disk)

\begin{tabular}{|c|c|c|c|c|c|}
\hline Type of elect. & Elect.Dia. & Current & Arc time & Consumption & Remarks \\
\hline Pure W & $2.4 \mathrm{~mm}$ & $\operatorname{DCsP} 250 \mathrm{~A}$ & $30 \mathrm{~min}$ & $9.56 \mathrm{mg}$ & \\
\hline$"$ & $"$ & $"$ & $" \prime$ & 24.61 & \\
\hline$T h-W$ & $" \prime$ & $"$ & $"$ & 9.44 & \\
\hline$"$ & $"$ & $"$ & $" \prime$ & 15.41 & \\
\hline Pure W & 2.4 & $\frac{\text { AC } 150 \mathrm{~A}}{\text { (Unbalanctd) }}$ & 30 & 299.67 & Remarkable sputtering \\
\hline$"$ & $u$ & $" \prime$ & $\prime \prime$ & 48.75 & Sputtered at start \\
\hline Th-W & $"$ & $"$ & $n$ & 16.00 & \\
\hline$"$ & $"$ & $" \prime$ & $"$ & 66.48 & \\
\hline
\end{tabular}

* The arc is missed during reverse polarity half cycle

タートに先立ってシールドガス流を開始するように注意

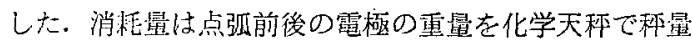
して求め，わずかな酸化や污れの影響む一応チェックし た.また試料電極はいずれも未使用の新しいものを用い た.

この結果，母板が水冷銅またはアルミニウムのときは DCSP アークにおける電極消耗量はせいぜい数 $\mathrm{mg} / 30$ min.であり。電極の太さ抢よび電流の大さにつ礼て增 すが比例的にまではいたららない，また時間とと屯に增す が，消耗率は時間とともに減少の㑯问が苟る。これは初 期には不純分の影響が勃き，時間が経つにつれ先端部の 不純分が減少するためではないかと考えられる，交流で は直流の 2 ～倍になるようであるが，測定した範囲で は $10 \mathrm{mg} / 30 \mathrm{~min}$. 在越えるようなときは，スパッタや 酸化などの異常が認められている．また消耗量は時間と とすに増してはいるが、ばらうきが大きい。

交流で，直流分のある場合上ない場合とでは電流容量 あるいは電極先端の溶球の大さがいちじるしく異なり， 直与に比較するには問題があるが，平衡交流に上る少数 の試験は此較的高い消耗を示しているままた純タンとト リタンの比較では概して純タンのほうが消耗がやや高い ように認められる。なお，筆者の測定值は全般に他の文 献にみられるものよりも低い值であるが；試料が限られ たものであるから理由は明らかになし難い。ただし，ア ルゴン中に不純物として酸素があるとみられるようなと きは高い消耗を示すから ${ }^{13}$ 従来の測定で使用されたアル ゴンガスが現在のものより純度が少っていたかもしれな いことなども考えられる。

タングステンの蒸発速度については参照すべき十分な 知識がないが， $0.025 \mathrm{~mm} \times 1 \mathrm{~cm}$ 角の薄膜（約 $48 \mathrm{mg}$ ） が， その融点近くの温度で蒸発しつくすのに 1 数時間 程度（文献 14 の外扦による推定）要するようであるか
ら，電極の場合蒸発面積の評侕がはっきりしないが，少 なく上手純タンでは，その消耟は概极蒸発に上るもの上 みてよいであろうと考えられる。

母板が鉄の之きは（Table 12）以上の場合の10倍近い 消耗がみら机る．との場合電極の先端に近い部分は銀光 沢のままであばた状の損耗を生じており，また溶融池か らのスパッタがいちじるしい，乙の事実はすでに一部の 人によって指摘さ机ており，電極表面㣂点の低い夕ン グステン一鉄の合金が生ずるためとされているが必ずし も確認はされていないであるう。この点は別途研筑すべ きものである。

\section{2 スパッタなどの異常消耗}

一般にスパッタの生ずる条件は明らかでなかった，ス

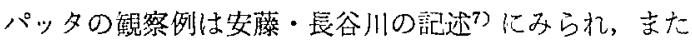
他の人々によっで2)古経験され，軟鋿を母材にするとき にいちじるしいらしいということす言われている。

また了ルミ合金の欠宿検查基準作成のために行なわ礼 た研究15)ではタングステンインクルージョンをもつ試験 片を得るために，それぞれ $1.6 \mathrm{~mm}$ 径電極に交流 120 $130 \mathrm{~A}, 2.6 \mathrm{~mm}$ 径保 $205 \sim 215 \mathrm{~A}, 3.2 \mathrm{~mm}$ 径江 $240 \sim 250$ あるいは 260〜270 A なよ゙のアーク電流を使用して JIS 3，7〜10 級に当る欠陷試料を得ており，乙れらはいずれ む Table 7 の許容最大電流を越えるものであるが，し かしてのようなときも一般には必ずしも継続的または頻 発的なとまかいスパッタが起るとは思われないから，こ れらは電極先端の大きな溶球を手の操作で振り落すよう にしたか，または母材に接触せしめたかその他の異常な

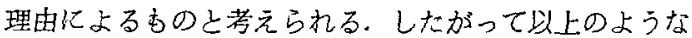
スパッタは経験の再現性すらむ必ずしも確かでない．

(筆者の経験では普通の使用条件の簿囲では認めら机な かった).

てれに反してアークスタート時のスパッタはよく知它 
れ，長谷川7), Gibson ${ }^{2)}$, Winsor ${ }^{4)}$ らによって屯若干の 試験結果が示されている.

筆者はかなり速く移動 $(8.4 \mathrm{~cm} / \mathrm{sec})$ させつつある銅 板 (5 mm 厚) 上に種々の条件でアークを発生させ,つ ぎのような事実を見出した，すなわち，スタート時スパ ッタが顕著に起るのは，以前に一度以上アークを点じた ことのある純タングステン電極に, DCRP の最大許容電 流值に近い電流を急に課した時である，つぎの場合には スパッタは全くあるいははとんど起らない。（1）トリ タン, (2) 純タンの処女棒, (3) アークスタート時の 電流が小さいとき，ただしトリタンであ逆極性アークを 点じて先端を溶融させたすのに正極性の大きな電流を課 すればスパッタを生じうる。

Fig. 13 は顕著にスパッタを生ずる例であるが，最大 のスパッタの落下しているのはアーク開始点より約1秒 後の地点であり, 最後のスパッタはアーク開始の約 $1 / 4$ 秒 後に生じている. Fig. 13 の上方の写真は最後のスパッ タの落下直後のスナップ写真であり, 電極の先端がなお 円錐状に凸起しているのが注目される．純タン電極の先 端部には多くの場合気泡を生じているととが見られてい るが，（Fig. 1）アーク発生時の熱衝撃でこの部分が一 種の爆発をすることによりスパッタを生ずるものと考え られる。

Fig. 14 はたまたま観察された別の例であるが，ア一 ク発生中 (DCSP) 約 10 分目毎に電極先端に凸起の生成 消滅を生じた (右下の写真). 凸起のいちじるしいとき にアークを止めて電極断面を研磨したのが左方の写真で 空洞がみられる先端部は研磨の具合で開放しているよう にみえているが，実際は薄い壁で閉じている．この凸起 は暫時後内部の空洞からガスを放出したようになって右 上の写真のように収縮するけれども，この前後で電極を 科量するとほとんど減量がない.すなわち単なる空洞の 生成だけではスパッタは起らず，スパッタが起るにはア 一ク発生時のような熱衝撃を必要とするものと解され る.

類似の電極先端の凸起は純タングステンで，直流分を 含む交流アークの正極性半サイクルにおいて常時観察さ れる. これはトリタンの場合や, 純タンでも電流が小さ いか平衡交流のときはいちじるしくは起らない。これが スパッタに関係があるかどうか明らかではないが，つぎ のものは興味ある例である.

すなわち, Table 12 の下部に示したのは軟鋼を母板 として交流アークを発生したが, 逆極性半サイクルのア ークがすぺて miss して, 正極性半サイクルのみのアー クとなったてとがオッシログラフにより確められた。 と の場合連続的なスパッタを生じ, 表に示したようないち
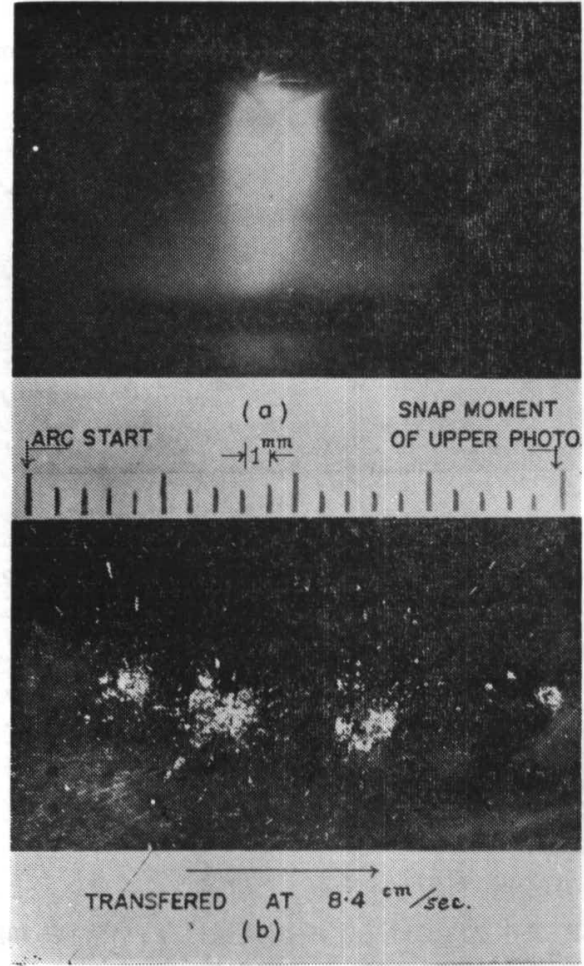

Fig. 13 Tungsten sputters at arc initiation on copper plate which is transfered at speed of $8.4 \mathrm{~cm} / \mathrm{sec}$. (3.2 $\mathrm{mm} \phi, 470$ A DCSP)

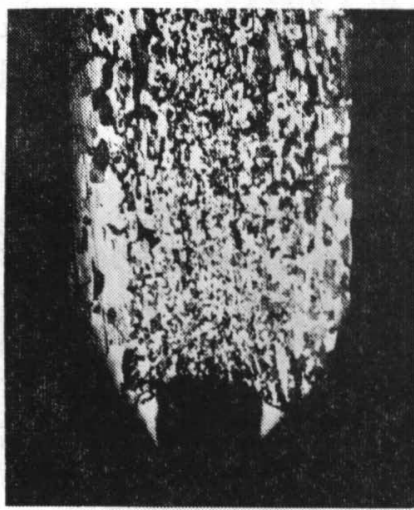

ETCHEO LONGITUDINAL SECTION (a)

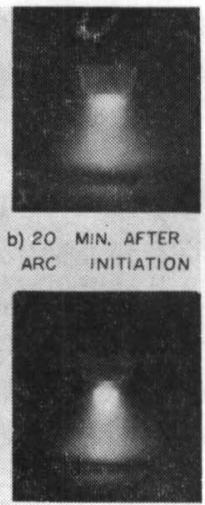

c) 29 MIN. AFTER ARC INITIATION
Fig. 14 The formation of projection and cavity at the tip of W-electrode

じるしい消耗を生じたあのである．これから考えると， この種のスパッタは熱衝撃と尖頭電流によるいちじるし いPinch 効果が主原因であると考えられる．一般に軟 鋼の溶接に交流タングステンアークを用いることは推奖 されていないことであり，この種の問題は本研究の範囲 外であったが，なお今後の検討の余地があろう. 


\section{5. 結論}

以上の研究により得られた結果を䈏条的に記せば以下 のようである.

（1）直流正極性アークにおりる電流容量はジュール 熱したがって電極径と突出長さによってきまり，Fig. 5 のグラフまたは式（1）の実験式によって表わされる.

（2）アルゴンシールド直流正極性アークでは電流容 量は純タンとトリタンとではとんど変りがなく，むしろ 後者のほうがわずかに低い。

（3）直流逆極性アークでは電流容量は明確な臨界值 をむって示すととができず，実用的見地からの判断でき められる。

（4）交流アークに扔いてはいわゆる直流分を生ずる が，その实測結果は Fig. 8,9 および Table 6 亿示され る.

（5）交流アークの電流容量は Table 7 亿示され， 不平衡交流では電極の破壊は径の小さいときはS.P 型, 大きいときは R.P 型である．直流分の多少によって大 きく変化するが，その関係住理論的考察に基いて概ね式 （5）であたえられると考えられる．また純タンとトリ タンでは後者のほうか電流容量が相当大きい.

（6）スタートスパッタなざを抑制した注意深い実験 によれば，水冷銅またはアルミ二ウムを母板とする直流 正極性アークにおりる電極の消耗は数 $\mathrm{mg} / 30 \mathrm{~min}$ 程度 にすぎず，これは概权純粋の蒸発によるるのと見なされ る.

（7）上記の条件で交流アークの場合は消耗が $2 \sim 3$ 倍になる。

（8）軟鋼を母板とするときは10倍近い消耗を生じ， とくに交流アークではスパッタを伴うことがある.

（9）直流正極性アークにおいてスタート時に生ずる スパッタは，以前に一度以上アークを点じたてとのある 純タン電極に最大電流做に近い電流を急に課した場合に だけ必ず起り，つぎの場合には全くあるいはほとんど起 らない（a）トリタン（b）純タンの処女棒 (c) アークスタート時の電流が十分小さい上き，また卜リタ ンで屯逆極性アークを点じて先端を溶融させたのち正極
性の大きな電流を課すればスパッタを生じうる.

（10）スタートスパッ夕はアーク発生後約 $1 / 4$ 秒以内継 続する。

（11）スタートスパッタの原因は電極先端部に生ずる 気泡と熱衝撃によるものと見られる。

なお，以上の試験は限られた試料基くむのであって 電極材料の化学成分，材質などとその性質との関係につ いては別途の試験にまたねばならない。

本研究は溶接協会電気溶接機部会で行なった共同研究 に関連して筆者が行なったもので，試料の大部分は同部 会で都合していただいたものであり，また大阪大学安藤 教授と西川浮氏，東芝浜川崎工場石井良一民ら纪多大の 御指導御教示を受けたととを記して感謝するしだいであ る.

\section{参考文 献}

1) Linde's manual, How to weld with with Heliarc torches,

2) G.J. Gibson, R.O. Seitz, Thoriated-Tungsten Electrodes-Their Welding characteristics and Applicatons, W.J. Vol. 31 (1952) No. 2 p. 102-108

3) N.A. Chapin, J.D. Cobine, C.J. Gallagher, Tungsten. Thoria Electrodes for Inert Arc Welding. W.J. Vol. 30 (1951) No. 6, p. 529-531

4) L. P. Winsor, R. R. Turk, A Comparative Study of Thoriated, Zirconiated and Pure Tungsten Electrodes. W.J. Vol. 36 (1957) No. 3, p. 113 S-119 S

5) H.A. Huff, Some Practical Considerations in the Application of Tungsten Arc Welding. W.J. Vol. 33 (1954) No. 9, p. 871

6）浴接協会電気溶接機技術委員会㷵料（昭和 37 年 8 月），ティグ溶接 用タングステン電極椿規格 (案)

7) 安藤，長谷川：浴接フーク現参（昭37.7） p. 148-153， p.377-379

8) R.W. Tuthil, The Effect of Wave Shape in Inert.Arc Welding Circuits, W.J. Vol. 27 (1948) p. 785

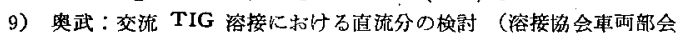
資料 L-114, 䀡37.7.7)

10) R.W. Tuthill, Weld. Eng. Vol. 34 (1949) p. $42-45$

11) G. Urbain, Measuring the Tungsten Comsumption in Inert gas Arc Welding, W.J. Vol. 30 (1951) No. 5, p. $260 \mathrm{~S}-264 \mathrm{~S}$

12) H. Mikkmi, M: Suzuki, R. Ishii, A Report on the phenomena of the Tungsten Electrodes in TIG welding (Report 1,2) IIW Doc. 1962

13）小沢その他：タングステンフーク電拪の消粍現象 溶接学会能 Vol. 28 (1959) No. 4 p. 250-254

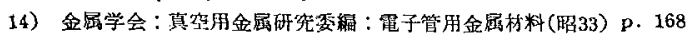

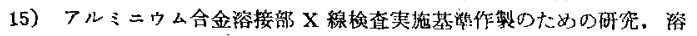
接技術 Vol. 18 (1960) No. 10, p. 698-735 